\title{
Peripheral clearance of brain-derived $A \beta$ in Alzheimer's disease: pathophysiology and therapeutic perspectives
}

\author{
Yuan Cheng ${ }^{1,2,3}$, Ding-Yuan Tian ${ }^{1,2,3}$ and Yan-Jiang Wang ${ }^{1,2,3,4^{*}}$ (D)
}

\begin{abstract}
Alzheimer's disease (AD) is the most common type of dementia, and no disease-modifying treatments are available to halt or slow its progression. Amyloid-beta $(A \beta)$ is suggested to play a pivotal role in the pathogenesis of $A D$, and clearance of $A \beta$ from the brain becomes a main therapeutic strategy for AD. Recent studies found that $A \beta$ clearance in the periphery contributes substantially to reducing $A \beta$ accumulation in the brain. Therefore, understanding the mechanism of how $A \beta$ is cleared in the periphery is important for the development of effective therapies for AD. In this review, we summarized recent findings on the mechanisms of $A \beta$ efflux from the brain to the periphery and discuss where and how the brain-derived $A \beta$ is cleared in the periphery. Based on these findings, we propose future strategies to enhance peripheral $A \beta$ clearance for the prevention and treatment of $A D$. This review provides a novel perspective to understand the pathogenesis of $A D$ and develop interventions for this disease from a systemic approach.
\end{abstract}

Keywords: Alzheimer's disease, Beta-amyloid (Aß), Blood-brain barrier, Lymphatic vessel, Venous sinus, Periphery, Liver, Kidney, Intestine, Skin, Blood, Monocyte, Enzymes

\section{Background}

Alzheimer's disease (AD) is the most common form of dementia, and disease-modifying therapies are not available to date. The extracellular senile plaques formed by the deposition of amyloid-beta $(\mathrm{A} \beta)$ peptide are the specific hallmark of $\mathrm{AD}$. $\mathrm{A} \beta$ is generated from sequential cleavages of the amyloid precursor protein (APP) by BACE-1 and the $\gamma$-secretase complex. Compelling evidence supports the pivotal role of $A \beta$ in the pathogenesis of AD. This evidence includes the following: (1) overproduction of $A \beta$ in the brain owing to mutations of APP or presenilin genes $1 / 2$ (PS1/2) in familial AD and an additional copy of the APP gene in Down syndrome

\footnotetext{
*Correspondence: yanjiang_wang@tmmu.edu.cn

'Department of Neurology and Centre for Clinical Neuroscience, Daping Hospital, Third Military Medical University, Chongqing, China

${ }^{2}$ The Institute of Brain and Intelligence, Third Military Medical University, Chongqing, China

Full list of author information is available at the end of the article
}

clearly causes AD-like dementia [1]. (2) Reduction of A $\beta$ production due to a missense mutation (p.A673T) in the APP gene results in a reduced risk for AD in an Icelandic elderly population [2]. (3) The apolipoprotein E (ApoE) $\varepsilon 4$ allele, the strongest genetic risk factor for $\mathrm{AD}$, is closely involved in the regulation of $A \beta$ metabolism [3]. (4) In the trajectory of $A D$, abnormal $A \beta$ accumulation precedes neurodegeneration and cognitive decline in both familial $\mathrm{AD}$ and sporadic $\mathrm{AD}[4,5]$. This evidence suggests that the abnormal metabolism of $A \beta$ in the brain plays a central role in the pathogenesis of $\mathrm{AD}$.

Converging data from animal models and clinical studies have demonstrated that abnormal $A \beta$ accumulation in the brain causes neurodegeneration, neuroinflammation, impaired neuronal function, and ultimately cognitive decline. This process is mainly caused by the overproduction of $A \beta$ due to mutations in the APP and $\mathrm{PS} 1 / 2$ genes in familial AD, which accounts for $1 \%$ of 
total $\mathrm{AD}$ patients, while dysfunction of $\mathrm{A} \beta$ clearance is hypothesized to be the main reason for $A \beta$ accumulation in sporadic $\mathrm{AD}$, which accounts for $99 \%$ of total $\mathrm{AD}$ patients [6]. Therefore, improving $A \beta$ clearance has become a promising therapeutic strategy for $\mathrm{AD}$ [7]. Indeed, several potential pathways have been shown to be involved in $A \beta$ clearance from the brain, including phagocytosis and endocytosis by various cells, such as microglia, perivascular macrophages and astrocytes, and proteolytic degradation by enzymes, including neprilysin (NEP), insulin-degrading enzyme (IDE) and matrix metalloproteinases (MMP). Recent studies have shown that high levels of $A \beta$ could flow from the brain to the periphery, and physiological catabolism of brain-derived $A \beta$ in the peripheral system has been revealed in both humans and mice [8], providing a novel perspective for understanding the pathogenesis of and developing therapeutics for $\mathrm{AD}$. The aim of this review is to discuss the recent findings on the peripheral clearance of $A \beta$ and its potential for $\mathrm{AD}$ prevention and treatment.

\section{Main text}

Mechanisms of $A \beta$ efflux from the brain to the periphery Several pathways, including the blood-brain barrier pathway, lymphatic-related pathway and arachnoid granule pathway, have been shown to mediate $A \beta$ effluxes from the brain into the periphery.

\section{Blood-brain barrier pathway}

Numerous studies have suggested that pathological changes in the neurovascular unit, which includes clusters of glial cells, neurons and pericytes, contribute to the onset and progression of $\mathrm{AD}$ and support a link between blood-brain barrier (BBB) dysfunction and neurodegeneration [9]. In addition, the capillary length in the mouse and human brain is approximately $0.6 \mathrm{~km}$ and $650 \mathrm{~km}$, respectively, which accounts for $>85 \%$ of the total cerebral blood vessel length, providing a large endothelial surface area for substance exchanges between the blood and brain. The BBB is, therefore, considered to be the primary approach to eliminate pathological molecules such as $A \beta$ from the brain [10].

$A \beta$ efflux is normally mediated via its receptors on the brain endothelium, and the clearance mechanism is mainly mediated by cell surface proteins, mainly low density lipoprotein receptor-related protein 1 (LRP1), which localizes predominantly on the abluminal side of the cerebral endothelium [11]. Some LRP1 ligands codeposit with $A \beta$ in senile plaques and are involved in $A \beta$ clearance, such as ApoE, $\alpha 2$-microglobulin $(\alpha 2 \mathrm{M})$, and tissue-type plasminogen activator [12]. The affinity of $A \beta 40$ for LRP1 is higher than that of $A \beta$ peptides with a greater $\beta$-sheet content, such as $A \beta 42$, leading to $A \beta 42$ peptides being less efficiently cleared from the brain
[13]. Furthermore, the LRP1-mediated $A \beta$ clearance across the $\mathrm{BBB}$ was shown to be very rapid, with a rate of $0.21 \mathrm{pmol} \mathrm{A} \beta /$ minute/g interstitial fluid (ISF) for $A \beta 40$ and 0.11 pmol $A \beta /$ minute/g ISF for $A \beta 42$ [14].

LRP1 works closely with phosphatidylinositol-binding clathrin assembly protein (PICALM) to clear A $\beta$ monomers, oligomers, and aggregates from the brain across the $\mathrm{BBB}$. Another key protein, P-glycoprotein (Pgp, also known as $A B C B 1$ ), which localizes predominantly on luminal membranes of brain endothelial cells, also mediates the active efflux of $A \beta$ from the brain to blood. Due to its special anatomical location, LRP1 has been suggested to facilitate the initial uptake of $A \beta$ from the ISF, followed by Pgp pumping A $\beta$ out of the endothelial cells into the blood $[15,16]$. In addition, LRP2, the largest receptor of the low-density lipoprotein receptor (LDLR) family, facilitates the endocytosis of $A \beta$ as well as its clearance across the BBB after binding to apolipoprotein J (ApoJ, also named clusterin) [13]. In addition to these mechanisms, some other receptors mediate $A \beta$ efflux, such as insulin-sensitive transporters and ANP-sensitive transporters [17]; however, the relative contribution of these receptors remains unclear, and more research is required to elucidate their role in the pathogenesis of AD.

In contrast, circulating $A \beta$ enters the brain mainly through receptor for advanced glycation end products (RAGE), a multiligand influx receptor in the immunoglobulin superfamily that is expressed on the luminal surface of brain vessels [18]. The BBB levels of LRP1, Pgp, and RAGE are changed in AD models before $A \beta$ deposition, which may contribute to $A \beta$ accumulation in the brain [10].

\section{Arachnoid granule-venous sinus pathway}

The role of the $\mathrm{BBB}$ in material exchange and transportation is well known; however, there are still other ways to transport brain-derived metabolites to the periphery. Several lymphatic-related clearance routes and arachnoid granule pathways drain solutes from the brain into the periphery.

Cerebrospinal fluid (CSF) is also directly drained to peripheral blood via arachnoid villi and granulations in the walls of major venous sinuses [19]. The bulk flow of CSF into the blood appears to occur via large vacuoles that form on the abluminal side of the endothelial cells, passage through the cells and release of the contents into the venous blood [20]. The majority of the CSF in humans appears to drain by this route; however, in newborn lambs, the nasal pathway is the primary route, as arachnoid villi do not develop until later in development $[21,22]$. In addition, there is considerable species variation in the size and structure of arachnoid villi and granulations; for instance, arachnoid villi of experimental 
animals are much smaller and simpler than human arachnoid granulations, suggesting that animal studies may not truly reflect human physiological condition. Therefore, the contribution of arachnoid granule-venous sinus pathway in transporting $\mathrm{A} \beta$ and other metabolites from the brain to the periphery in human needs to be investigated.

\section{Lymphatic-related pathways}

The first lymphatic pathway is the meningeal lymphatics at the bottom of the rodent skull, which are specialized to drain CSF to deep cervical lymph nodes, allowing wastes and other macromolecules to leave the brain [23]. However, the contribution of lymphatics in draining $A \beta$ out of the brain is unclear, although disruption of meningeal lymphatics accelerates $\mathrm{AD}$ pathologies in the brain of animal models [24]. The meningeal lymphatics have also been revealed in human beings [25], their physiological functions in maintaining the brain homeostasis and their aberrant alterations in the pathogenesis of AD remain largely unknown. But the finding of meningeal lymphatics provides a novel perspective to understand the process of $A \beta$ clearance from the brain and suggests a new intervention approach for $\mathrm{AD}$.

The second lymphatic pathway is the perineural outflow pathways through which CSF drains to deep cervical lymph nodes. Emerging evidence has shown that CSF outflows along the cranial nerves, especially in the nasal or optical regions [26, 27]. More specifically, perineural drainage along the olfactory nerve, the first cranial nerve (CN I) through the cribriform plate to reach the nasal mucosa is considered to be the most important CSF lymphatic outflow route in several species [27-30]. In addition, the optic nerve ( $\mathrm{CN}$ II) and trigeminal nerve (CN V) exhibit a perineural pattern [27]. All these pathways are potential drainage routes to clear toxic proteins, such $A \beta$, from the brain.

The third lymphatic pathway is the perivascular pathway which drains ISF from the brain to the cervical lymph nodes through basement membranes in the walls of capillaries, the tunica media of arteries, and the wall of the internal carotid artery in the neck [19]. $A \beta$ in the basement membranes of capillaries and artery walls in cerebral amyloid angiopathy (CAA) almost certainly blocks the perivascular drainage pathways, leading to increasing impedance of solute drainage from the brain. With advancing age, the artery walls become less elastic, and stiffening may interfere with perivascular drainage of ISF and solutes in elderly individuals [31].

The fourth lymphatic pathway is the paravascular space which is a narrow space between the irregular surface of the leptomeningeal and the outer basement membrane of the vessel walls and that of the glia endfeet $[32,33]$, and it has been proposed to be part of the glymphatic pathway [34]. This cortical paravascular route was referred to as the Virchow-Robin space (VRS); however, the exact boundaries of the VRS are not clearly defined to date. Paravascular drainage of solutes from the CSF appears to be dependent on the expression of aquaporin 4 (AQP4) and on efficient arterial pulsations, suggesting that pulsations in artery walls may generate the motive force for the transport of solutes out of the brain $[35,36]$.

There appears to be a difference in the drainage pathway between the CSF and ISF, and little is known about the proportion of ISF that drains into the CSF. A previous study indicated that $10-15 \%$ of the ISF drains into the CSF in rats [37], and a similar degree of drainage may occur in humans [19]. In addition, another research demonstrated that direct transport of $A \beta$ across the $B B B$ accounts for $\sim 25 \%$ of $A \beta$ clearance, and absorption of $\mathrm{A} \beta$ in the CSF accounts for $25 \%$ of the total CNS $A \beta$ clearance in humans [38]. However, the main mechanism through which $A \beta$ leaves the brain and the exact contributions of each of these pathways to overall $A \beta$ clearance remain unknown. Nevertheless, these pathways work synergistically to drain pathological proteins, such as $A \beta$, from the brain to the periphery, indicating that the peripheral tissues and organs are physiologically related to the metabolism of brain-derived wastes [39].

\section{Clearance of brain-derived $A \beta$ in the periphery}

It is estimated that $A \beta$ clearance via the $B B B$ is reduced by approximately $30 \%$ in $\mathrm{AD}$ patients [40]. However, the amount and mechanisms of $A \beta$ clearance in the periphery are poorly understood. Previous studies have suggested that approximately $40 \%-60 \%$ of brain-derived $A \beta$ is cleared in the periphery $[8,41,42]$. A recent study showed that deep cervical lymph node ligation aggravates the AD-like pathology of APP/PS1 mice [43], suggesting that blockage or dysfunction of the brain drainage routes is one of the factors that contribute to AD progression. Targeting meningeal lymphatics with vascular endothelial growth factor C (VEGFC), an essential growth factor for lymphatic endothelial cells, enhances the meningeal lymphatic drainage of CSF macromolecules and improves learning and memory performance in animals [24, 44].

All these findings imply that there are physiological mechanisms to transport pathological molecules from the brain to the periphery for clearance and suggest that peripheral clearance has a crucial role in removing brainderived $A \beta$. In the following section, we discuss where and how brain-derived $A \beta$ is cleared in the periphery.

\section{Blood component-mediated $A \beta$ clearance}

A recent study demonstrated that bone marrow transplantation reversed the age-related impairments in 
cognitive function and synaptic plasticity in aged mice [45]. Another study showed that bone marrow-derived cells contribute to the recruitment of microglial cells in response to A $\beta$ deposition in APP/PS1 mice [46]. Indeed, multiple components in the blood have been shown to participate in circulating $A \beta$ clearance.

Enzymes Secreted enzymes, which have an affinity for specific domains within the $A \beta$ amino acid sequence and an ability to cleave these peptides to shorter, more benign forms, are critical for the catabolism of circulating $A \beta$. These proteins include insulin-degrading enzyme (IDE), neprilysin (NEP) and its homologue endothelinconverting enzyme (ECE), angiotensin converting enzyme (ACE), matrix metalloproteinase-9 (MMP-9), and plasmin, the key enzyme of the plasminogen system.

IDE is a well-validated A $\beta$-degrading enzyme that was originally isolated as a molecule regulating plasma insulin levels. It is mainly a soluble cytoplasmic enzyme, although it also exists in a secreted form [47]. IDE activity levels were inversely correlated with brain $A \beta$ burden [48], and IDE knockout animals showed a significant increase in the brain $A \beta$ levels, suggesting that loss of this activity may contribute to AD pathology [49].

NEP is a ubiquitous circulating protease and is abundant in the kidney and the lung. NEP is considered to be the most potent $A \beta$-degrading enzyme $[50,51]$. NEP dysfunction elevates endogenous $A \beta$ levels in the mouse brain in a gene dose-dependent manner [52]. These findings suggest that NEP may have profound effects on $\mathrm{AD}$ pathogenesis by promoting $\mathrm{A} \beta$ clearance.

ACE is significantly expressed by the endothelium throughout the body and is known for regulating salt balance; this enzyme has also been shown to degrade $A \beta$ and, more importantly, cleave $A \beta 42$ into the less toxic A $\beta 40[53,54]$. Genetic studies have revealed a link between reduced plasma ACE levels and increased AD risk $[55,56]$. Furthermore, ACE overexpression by myelomonocytes leads to a reduction in brain $A \beta$ levels [57], indicating the potential role of ACE in $A \beta$ clearance. In addition, ECE-1, plasmin, and MMP-9 also participate in $A \beta$ degradation $[58,59]$, and compelling data support a major role of MMP-9 in the degradation of $A \beta$ compact plaques $[60,61]$, demonstrating its potent role in $A \beta$ clearance.

Monocytes Monocytes are a key component of the innate immune system and have multiple functions, such as the removal of debris and dead cells via phagocytosis. Multiple lines of evidence highlight the crucial role of monocytes in $\mathrm{AD}$. Circulating monocytes give rise to various tissue-resident macrophages throughout the body and specialized cells, such as microglia in the brain. Peripheral monocytes are found to be able to uptake $A \beta$ from the blood, and the phagocytosis of $A \beta$ by monocytes is compromised in AD patients [62, 63]. These findings suggest that monocytes might play a substantial role in clearing $A \beta$ from blood, and deficits in phagocytosis of $A \beta$ by monocytes would contribute to the pathogenesis of $\mathrm{AD}$.

Indeed, a decreased capacity of peripheral monocytes to capture $A \beta$ resulted in increased $A \beta$ levels [64]. In addition, the expression of monocyte cell adhesion molecules, such as ICAM-3 and P-selectin, was significantly reduced in $\mathrm{AD}$ patients, demonstrating that peripheral blood macrophages from $\mathrm{AD}$ patients displayed an impaired capacity to take up and digest $A \beta$ [65-67]. Moreover, the expression of surface receptor TREM2, which is involved in monocyte phagocytosis, and CD33, which is involved in $A \beta 42$ internalization, is altered in monocytes of $A D$ patients $[68,69]$, suggesting that $A \beta$ clearance by monocytes plays a substantial role in $\mathrm{AD}$ pathogenesis. Recent research has demonstrated that depletion of perivascular macrophages causes increased vascular $A \beta$ levels. However, stimulation of perivascular macrophage turnover decreased the cerebral CAA load, highlighting the importance of perivascular macrophages in this AD-related disease [70]. Patrolling monocytes have been shown to infiltrate the brain and differentiate into activated macrophages in $\mathrm{AD}$ [71], and these circulating monocyte-derived macrophages are more efficacious than resident microglia in clearance of $A \beta$ plaque in the brain [72]. The circulating monocyte subset could adhere to the $A \beta$-rich vasculature in the brain and effectively eliminate $A \beta$ microaggregates by internalizing and transporting them from the brain vasculature to the blood [71]. Taken together, these observations outline the crucial role of the monocyte-mediated clearance of $\mathrm{A} \beta$ in both the brain and the periphery in AD.

Erythrocytes Recent evidence suggests that $A \beta$ is subject to erythrocyte-mediated immune adherence at every step in the pathway, where $A \beta$ activates serum complement, and complement-opsonized $\mathrm{A} \beta$ peptides are captured by erythrocytes via CR1 and transported to liver and spleen for clearance [73, 74]. CR1 is deficient in erythrocytes of $\mathrm{AD}$ patients, and the single nucleotide polymorphisms (SNPs) associated with decreased erythrocyte $\mathrm{CR} 1$ increase $\mathrm{AD}$ risk, whereas a CR1 SNP associated with increased erythrocyte CR1 reduces $A D$ risk [75]. These findings are helpful to establish a mechanistic link between the CR1 polymorphisms and their risks for $\mathrm{AD}$ [76]. Furthermore, it was recently found that $A \beta$ antibodies can dramatically increase complement activation and opsonization of $A \beta$, and therefore enhance $A \beta$ capture by human erythrocytes and macrophages [77]. These findings suggest that the peripheral mechanism cannot be ignored for the $A \beta$ clearance by 
immunotherapies, and infer the potential roles of interaction between autoantibodies to $A \beta$ and erythrocytes in the pathogenesis of $\mathrm{AD}$. It is also found that the number of erythrocytes is less in $\mathrm{AD}$ patients than in cognitively normal control [78]. Taken together, these studies suggest that erythrocyte-mediated clearance, a major pathway for clearance of circulating pathogens, is a substantial approach for the clearance of circulating $A \beta$.

\section{Liver-mediated $A \beta$ clearance}

When flowing into the periphery, $A \beta$ usually binds to other molecules. Previous studies have demonstrated many transport proteins, such as albumin, ApoE, ApoJ, transthyretin (TTR), and $\alpha-2 \mathrm{M}$ could bind $\mathrm{A} \beta$ [79-83]. However, in human plasma, the soluble form of LRP1, which sequesters $70 \%-90 \%$ of plasma $A \beta$, is the major binding protein for circulating $A \beta$ and mediates peripheral $A \beta$ degradation in the liver, kidneys and spleen [84].

The liver has many functions, including endocrine function, immunomodulation, lipid metabolism, and detoxification, which may all be involved in AD pathogenesis. It is proposed that once efflux from the brain occurs, $A \beta$ is transported to the liver by high-density lipoprotein (HDL) particles [85-87], indicating the participation of the liver in peripheral $A \beta$ clearance. Hepatocytes can act on circulating $A \beta$ via LRP1, which is highly expressed in hepatocytes, promoting its clearance by degradation or through bile excretion [88]. Moreover, upregulating liver LRP1 expression could reverse the behavioural deficits and pathologies in the brain of APP/PS1 models [89], indicating that targeting peripheral organs, such as the liver, offers a unique therapeutic approach for $A \beta$ clearance. In addition, the function of central circadian rhythms could influence $A \beta$ pathogenesis in a specific manner [90]. Given that the liver is the main peripheral organ communicating with brain via the liver-brain axis, the liver might affect $A \beta$ clearance by regulating the circadian rhythm [91]. These findings highlight the importance of the liver in $A \beta$ clearance and the pathophysiology of AD.

\section{Kidney-mediated $A \beta$ clearance}

Kidney is the main excretory organ and control levels of metabolites via regulating and filtering minerals from blood. Recent researches indicated that kidney may be involved in circulating $A \beta$ clearance. Indeed, radiographic experiments have shown that after intracranial or intravenous infusion of $\mathrm{I}^{125}$-labelled $\mathrm{A} \beta$, radioactivity was subsequently detected in the kidney and urine [8], besides, soluble $A \beta$ was also detected in human urine [92]. These evidence all suggest that kidney might participate in physiological clearance of $A \beta$ by filtering $A \beta$ from the blood to the urine. In addition, the serum $A \beta$ levels and brain $A \beta$ depositions were found to be significantly increased in chronic kidney disease (CKD) patients [93, 94], indicating that the reduced kidneymediated $\mathrm{A} \beta$ clearance may contribute to $\mathrm{AD}$ pathology in brain. Furthermore, clinical studies demonstrated the link between CKD and risk of cognitive impairment [95-97], which even independent of cerebral smallvessel disease [98], implying that $A \beta$ accumulation caused by aberrant kidney-mediated excretion may be involved in cognitive impairment in CKD patients. These studies suggest that kidney-mediated $A \beta$ excretion have a significant impact on removing $A \beta$ in the brain.

\section{Are intestine and skin involved in peripheral A $\beta$ clearance?}

A previous study reported the detection of $A \beta$ deposits in the non-neural tissues of $\mathrm{AD}$ patients, including the skin and intestine in humans [99] and the gastrointestinal tract in animals [100]. The source of $A \beta$ deposits in the intestine and skin is probably derived from circulating $A \beta$ in the blood, implying that the intestine and skin may participate in peripheral $A \beta$ metabolism.

The gastrointestinal tract is a lymphoid organ, which is heavily laden with macrophages and other immune cells. This implies that the gut has the potential capacity of clearing $A \beta$. Increasing data demonstrate that gut microbiota is altered in $\mathrm{AD}$ patients $[101,102]$, suggesting that the braingut-microbiota axis is involved in the pathogenesis of $\mathrm{AD}$. It is intriguing to speculate that gastrointestine may have the function of regulating $\mathrm{A} \beta$ metabolism in the periphery.

Skin has been defined as an immune organ for a long time. The skin and brain, both derived from ectoderm of embryo, are physiologically and pathologically connected. Newly published data suggested that $A \beta 34$, an $\mathrm{A} \beta$ species with specific length, was found in the epidermal layer in human skin [103]. The deposition of $A \beta$ was also found in the skin of AD patients [99]. Although APP expression was detected in situ in the mammalian epidermis and predominantly in basal keratinocytes $[104,105]$, it remains unknown whether these $A \beta$ deposits are from circulating blood or local cells in the skin. Our previous studies found that radiolabelled $A \beta$ mainly accumulated in the skin after intravenous injection [8]. These findings suggest that skin may be involved in the metabolism of $A \beta$ in the periphery. In the skin there are many macrophages which may clear local $A \beta$. In addition, the secretion of sweat is a potential approach to excrete $A \beta$. Nevertheless, whether skin functions in $A \beta$ clearance remains largely unknown. Future studies are needed to address this topic.

\section{Do systemic diseases increase the $A D$ risk via the peripheral $A \beta$ clearance approach? Disorders of systemic immunity and inflammation}

Immune system abnormalities are now considered a major pathological factor in $\mathrm{AD}$, and innate immunity is 
compromised in patients with AD. Reduced expression of $A \beta$ phagocytic receptors and $A \beta$-degrading enzymes and decreased phagocytic function in mononuclear macrophages and neutrophils might impede $A \beta$ degradation and clearance [106-108]. In regard to adaptive immunity, autoreactive antibodies related to $\mathrm{AD}$ pathogenesis have been studied. Specifically, elevated levels of pathogenic autoreactive antibodies and decreased levels of protective antibodies could influence $A \beta$ clearance and deposition. In addition, compelling evidence suggests that chronic systemic inflammation, such as rheumatoid arthritis and periodontitis, promotes the AD pathogenesis $[109,110]$. Proinflammatory molecules, such as TNF- $\alpha$, IL- 6 and IL- $1 \beta$, could compromise A $\beta$ clearance by affecting the functions of not only microglia but also peripheral monocytes and $A \beta$-degrading enzymes [111].

\section{Hepatic dysfunction}

The liver is the major organ responsible for system-wide protein synthesis and metabolic detoxification. Circulating $A \beta$ is directly cleared by degradation in hepatocytes or indirectly cleared by regulation of the liver-mediated albumin level and $A \beta$-related lipid metabolism. Our previous study suggests that hepatic dysfunction, such as liver cirrhosis, is accompanied by higher levels of circulating $A \beta$. The reduced hepatic LRP1 levels in ageing rats contributed to decreased peripheral $A \beta$ clearance $[88,112]$, suggesting that LRP1-dependent hepatocytemediated $A \beta$ clearance is potentially important [113]. In addition, a recent study found that an elevated AST/ ALT ratio and decreased levels of ALT were associated with $\mathrm{AD}$ brain biomarkers and poor cognitive performance [114], linking liver dysfunction to AD pathogenesis. Increasing evidence suggests that abnormal lipid metabolism is associated with an increased risk of AD [115], and some potential AD risk genes link to lipid metabolism [116]. Furthermore, ApoE, a liver-synthesized protein critical for $A D$ risk, could regulate $A \beta$ clearance via $\mathrm{BBB}$ transportation, enzymatic degradation and many other pathways [117].

\section{Renal dysfunction}

The kidney is traditionally considered to be an excretory organ, and soluble $A \beta$ is a normal component of human urine [92]. Patients with CKD have increased circulating $\mathrm{A} \beta$ levels [93] and decreased cognitive functions [95, 118]. $A \beta$ deposition is observed in the brains of CKD patients [94]. Furthermore, cerebral atrophy correlates with measures of renal function in patients with CKD [119]. These findings imply that the reduction in renal function may attenuate peripheral $A \beta$ clearance. Therefore, it is possible that cerebral $A \beta$ accumulation may be involved in the development of cognitive decline in CKD patients.

\section{Diabetes mellitus}

Numerous studies have demonstrated that patients with diabetes have an increased risk of developing AD [120]. The underlying mechanisms that link the development of diabetes with $\mathrm{AD}$ include the disorders of $\mathrm{A} \beta$ metabolism in both the brain and periphery. In patients with diabetes, excess insulin can competitively inhibit IDEmediated $A \beta$ degradation [49]. Moreover, diabetes also influences $A \beta$ clearance through other mechanisms, including oxidative stress, BBB disruption, the activation of inflammatory pathways, and hypercholesterolemia [121]. In addition, insulin resistance compromises intracellular translocation of LRP1 to the plasma membrane in hepatocytes, potentially hindering hepatic clearance of circulating $A \beta[112]$.

\section{Strategies for $A D$ therapies via peripheral $A \beta$ clearance}

Many strategies aim to alleviate $A D$ via peripheral $A \beta$ clearance. Here, we propose the following directions for future research (Fig. 1): (1) Maintaining the function of the $\mathrm{BBB}$ and brain lymphatic systems, which are critical for transporting $A \beta$ from the brain to the periphery, could promote brain $A \beta$ outflow and thereby attenuate $A \beta$ accumulation in the brain. (2) Peripheral organs, such as the liver and kidney, are thought to physiologically participate in $A \beta$ clearance. Whether liver or renal dysfunction also improves the $A \beta$ load in the brain remains to be answered. However, it is known that strengthening liver function via herbal medicine or kidney transplant can reduce the plasma $A \beta$ levels [94]. These findings suggest that improving the $A \beta$ clearance capacity of the liver and kidney has therapeutic potentials. (3) Mounting evidence has demonstrated the roles of the immune system in AD pathogenesis. A cluster of $\mathrm{AD}$ risk gene mutations have been found to compromise the phagocytic function of $A \beta$ by monocytes $[68,122]$. In terms of adaptive immunity, antibody-based immunotherapies have been tested for AD. In addition, immunePEGliposome and antibody-functionalized polymer nanoparticle have been used to ameliorate the AD pathology in animal models $[123,124]$. In these immunological modalities, the majority of antibodies locate in the blood and sequester peripheral $A \beta$ [125]. Therefore, improving the clearance of $\mathrm{A} \beta$ by peripheral immunomodulation and immune cells will be a promising therapeutic strategy [126]. (4) Improving $A \beta$ degradation by peripheral degrading enzymes is also a promising approach. Continuous expression of NEP in skeletal muscle or increased circulating NEP levels reduces the $\mathrm{A} \beta$ burden in AD mice $[127,128]$. Additionally, peripherally derived ACE-enhanced macrophages alleviate $A D$ pathology and behavioural defects [129]. These findings suggest that strengthening peripheral $A \beta$ degradation is a potential AD therapeutic approach. (5) Erythrocytes 


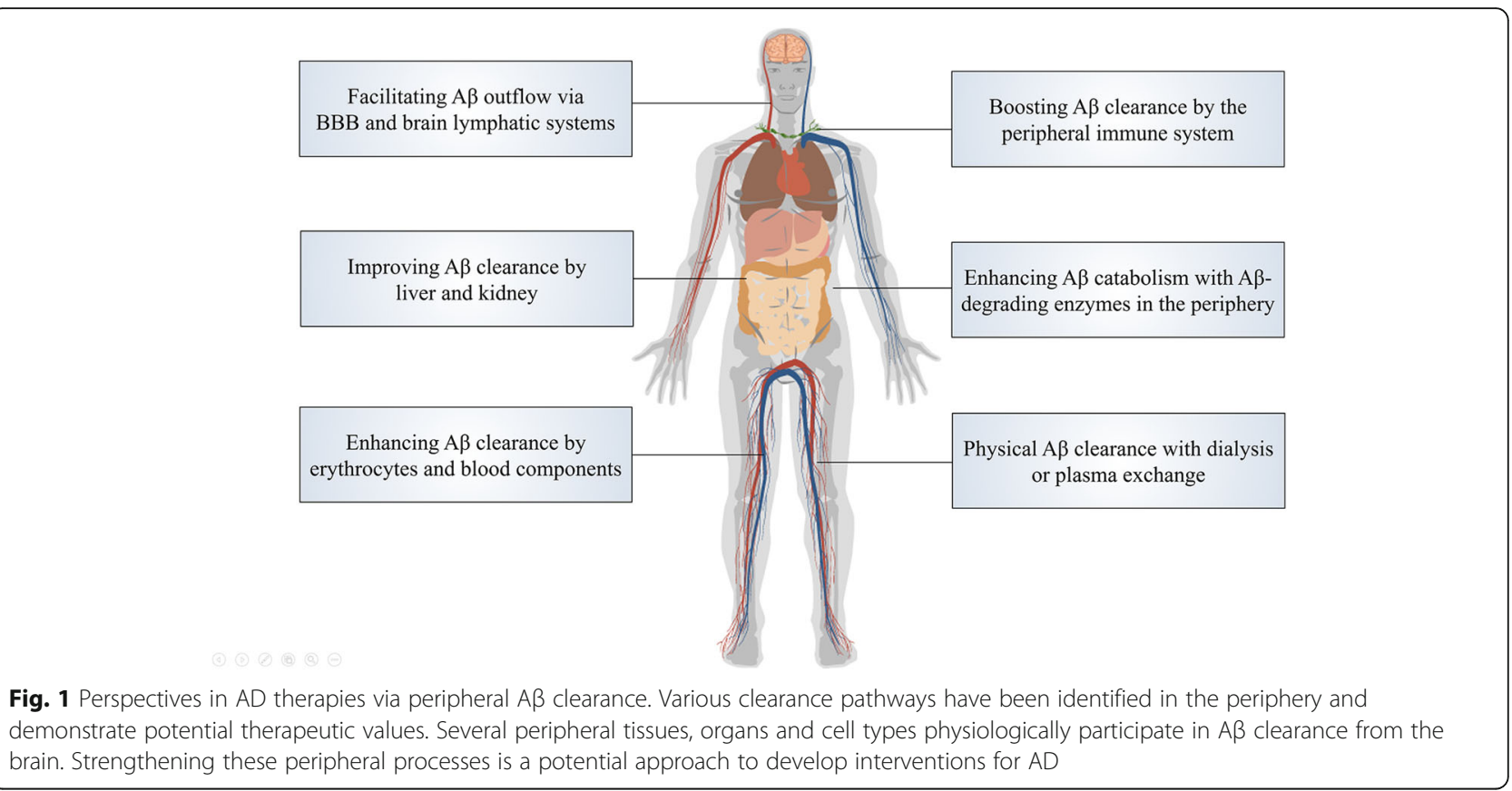

and albumin enable physiological clearance of $A \beta$ in the blood. This function can be used to develop the therapies to clear $A \beta$ in the brain [130]. (6) Plasma albumin exchange decreases the $A \beta$ burden in patients with $A D$ and improves AD-related cognitive function [131]. In addition, patients who have undergone haemodialysis exhibited a reduction in $A \beta$ deposition in the brain [94]. Furthermore, peritoneal dialysis reduces blood $A \beta$ levels in humans and attenuates AD pathology in an APP/PS1 mouse model [132]. These observations indicated that dialysis or plasma exchange would be a potential therapeutic approach [133].

All these data suggest that increasing efflux of brainderived $A \beta$ and strengthening peripheral $A \beta$ clearance can help relieve AD pathology. In addition, peripheral clearance is proposed to be a safer and easier therapeutic approach for $\mathrm{AD}$ than the traditional central clearance approach by introducing reagents into the brain [134]. In this regard, active removal of excess peripheral $A \beta$ seems to be a particularly promising therapeutic strategy for $\mathrm{AD}$.

However, it should be mentioned that some of the peripheral clearance pathways are not absolutely specific for $A \beta$. These approaches, such as $A \beta$-binding receptors (i.e. LRP1 and RAGE)-mediated BBB transport, enzyme (i.e. NEP and IDE)-mediated degradation, and erythrocyte-mediated immune adherence, also work for the clearance of other molecules or metabolites, implying that general enhancement of these clearance functions might cause adverse effects due to disturbance to the metabolism of other molecules. Therefore, $A \beta$ specific clearance methods are desirable for the development of AD therapies. Nonspecific mechanisms of $A \beta$ clearance could also be therapeutically tractable as long as their impacts to other substrates is evaluated to be safe. In addition, the $A \beta$ levels in the blood reflect the $A \beta$ metabolisms in both the brain and the periphery. For example, muscle cells can also produce and release $A \beta$ into the blood, and the $A \beta$ clearance by liver and kidney influences the $A \beta$ levels in the blood. This is may explain why $A \beta$ levels in the blood do not accurately reflect the amount of $A \beta$ levels in the brain.

\section{Conclusion}

As there is a close interaction between $A \beta$ metabolisms in the brain and the periphery [39], dysfunctions of $A \beta$ metabolisms in the periphery might contribute to the development of $\mathrm{AD}$, and targeting peripheral $\mathrm{A} \beta$ clearance represents a new opportunity for the prevention and treatment of the disease.

\section{Abbreviations}

AD: Alzheimer's disease; PD: Parkinson's disease; ALS: Amyotrophic lateral sclerosis; CKD: Chronic kidney disease; A : Amyloid-beta; NEP: Neprilysin; IDE: Insulin-degrading enzyme; MMP: Matrix metalloproteinases;

ECE: Endothelin-converting enzyme; ACE: Angiotensin converting enzyme; BBB: Blood-brain barrier; LRP-1: Lipoprotein receptor-related protein 1; a2M: Alpha-2-microglobulin; PICALM: Phosphatidylinositol-binding clathrin assembly protein; Pgp: P-glycoprotein; RAGE: Advanced glycation end products; CAA: Cerebral amyloid angiopathy; VRS: Virchow-Robin space; VEGFC: Vascular endothelial growth factor C; CR1: Complement receptor 1; GWAS: Genome-wide association studies; TTR: Transthyretin 


\section{Author's contribution}

$Y C$ reviewed the literature and drafted the manuscript. DYT reviewed the literature and contributed idea. YJW conceived this review and revised the manuscript. The author (s) read and approved the final manuscript.

\section{Funding}

This review was supported by the National Natural Science Foundation of China (grant no. 81930028, 91749206, 81625007 and 31921003).

\section{Availability of data and materials}

Not applicable.

\section{Ethics approval and consent to participate}

Not applicable.

\section{Consent for publication}

All authors read and approve of the final manuscript for publication.

\section{Competing interests}

The authors declare that they have no competing interests.

\section{Author details}

${ }^{1}$ Department of Neurology and Centre for Clinical Neuroscience, Daping Hospital, Third Military Medical University, Chongqing, China. ${ }^{2}$ The Institute of Brain and Intelligence, Third Military Medical University, Chongqing, China. ${ }^{3}$ Key Laboratory of Aging and Brain Diseases, Chongqing, China. ${ }^{4}$ Center for Excellence in Brain Science and Intelligence Technology, Chinese Academy of Sciences, Shanghai, China.

\section{Received: 12 January 2020 Accepted: 23 April 2020}

\section{Published online: 07 May 2020}

\section{References}

1. Goate A, Chartier-Harlin MC, Mullan M, Brown J, Crawford F, Fidani L, Giuffra $L$, Haynes $A$, Irving $N$, James $L$, et al. Segregation of a missense mutation in the amyloid precursor protein gene with familial Alzheimer's disease. Nature. 1991;349(6311):704-6.

2. Jonsson T, Atwal JK, Steinberg S, Snaedal J, Jonsson PV, Bjornsson S, Stefansson H, Sulem P, Gudbjartsson D, Maloney J, et al. A mutation in APP protects against Alzheimer's disease and age-related cognitive decline. Nature. 2012;488(7409):96-9.

3. Corder EH, Saunders AM, Strittmatter WJ, Schmechel DE, Gaskell PC, Small GW, Roses AD, Haines JL, Pericak-Vance MA. Gene dose of apolipoprotein E type 4 allele and the risk of Alzheimer's disease in late onset families. Science. 1993;261(5123):921-3.

4. Bateman RJ, Xiong C, Benzinger TL, Fagan AM, Goate A, Fox NC, Marcus DS, Cairns NJ, Xie X, Blazey TM, et al. Clinical and biomarker changes in dominantly inherited Alzheimer's disease. N Engl J Med. 2012;367(9):795-804

5. Sutphen $C L$, Jasielec MS, Shah AR, Macy EM, Xiong C, Vlassenko AG, Benzinger TL, Stoops EE, Vanderstichele HM, Brix B. Longitudinal cerebrospinal fluid biomarker changes in preclinical Alzheimer disease during middle age. JAMA Neurol. et al, 2015;72(9):1029-42.

6. Selkoe DJ, Hardy J. The amyloid hypothesis of Alzheimer's disease at 25 years. EMBO Mol Med. 2016;8(6):595-608.

7. Sun BL, Li WW, Zhu C, Jin WS, Zeng F, Liu YH, Bu XL, Zhu J, Yao XQ, Wang YJ. Clinical research on Alzheimer's disease: Progress and perspectives. Neurosci Bull. 2018:34(6):1111-8.

8. Xiang Y, Bu XL, Liu YH, Zhu C, Shen LL, Jiao SS, Zhu XY, Giunta B, Tan J, Song $W H$, et al. Physiological amyloid-beta clearance in the periphery and its therapeutic potential for Alzheimer's disease. Acta Neuropathol. 2015; 130(4):487-99.

9. Bell RD, Zlokovic BV. Neurovascular mechanisms and blood-brain barrier disorder in Alzheimer's disease. Acta Neuropathol. 2009;118(1):103-13.

10. Montagne A, Zhao Z, Zlokovic BV. Alzheimer's disease: a matter of bloodbrain barrier dysfunction? J Exp Med. 2017;214(11):3151-69.

11. Shibata M, Yamada S, Kumar SR, Calero M, Bading J, Frangione B, Holtzman DM, Miller CA, Strickland DK, Ghiso J, et al. Clearance of Alzheimer's amyloid-ss(1-40) peptide from brain by LDL receptor-related protein-1 at the blood-brain barrier. J Clin Invest. 2000;106(12):1489-99.
12. Rebeck GW, Harr SD, Strickland DK, Hyman BT. Multiple, diverse senile plaque-associated proteins are ligands of an apolipoprotein E receptor, the alpha 2-macroglobulin receptor/low-density-lipoprotein receptor-related protein. Ann Neurol. 1995:37(2):211-7.

13. Deane R, Wu Z, Sagare A, Davis J, Du Yan S, Hamm K, Xu F, Parisi M, LaRue $\mathrm{B}, \mathrm{Hu} \mathrm{HW}$, et al. LRP/amyloid beta-peptide interaction mediates differential brain efflux of Abeta isoforms. Neuron. 2004;43(3):333-44.

14. Bell RD, Sagare AP, Friedman AE, Bedi GS, Holtzman DM, Deane R, Zlokovic BV. Transport pathways for clearance of human Alzheimer's amyloid betapeptide and apolipoproteins $E$ and $J$ in the mouse central nervous system. J Cereb Blood Flow Metab. 2007;27(5):909-18.

15. Erickson MA, Hartvigson PE, Morofuji Y, Owen JB, Butterfield DA, Banks WA. Lipopolysaccharide impairs amyloid beta efflux from brain: altered vascular sequestration, cerebrospinal fluid reabsorption, peripheral clearance and transporter function at the blood-brain barrier. J Neuroinflammation. 2012;9: 150.

16. Hartz AM, Miller DS, Bauer B. Restoring blood-brain barrier P-glycoprotein reduces brain amyloid-beta in a mouse model of Alzheimer's disease. Mol Pharmacol. 2010:77(5):715-23.

17. Ito S, Ohtsuki S, Murata S, Katsukura Y, Suzuki H, Funaki M, Tachikawa M, Terasaki T. Involvement of insulin-degrading enzyme in insulin- and atrial natriuretic peptide-sensitive internalization of amyloid-beta peptide in mouse brain capillary endothelial cells. J Alzheimers Dis. 2014;38(1):185-200.

18. Deane R, Du Yan S, Submamaryan RK, LaRue B, Jovanovic S, Hogg E, Welch D, Manness L, Lin C, Yu J, et al. RAGE mediates amyloid-beta peptide transport across the blood-brain barrier and accumulation in brain. Nat Med. 2003;9(7):907-13.

19. Weller RO, Djuanda E, Yow HY, Carare RO. Lymphatic drainage of the brain and the pathophysiology of neurological disease. Acta Neuropathol. 2009; 117(1):1-14

20. Tripathi BJ, Tripathi RC. Vacuolar transcellular channels as a drainage pathway for cerebrospinal fluid. J Physiol. 1974;239(1):195-206.

21. Papaiconomou C, Bozanovic-Sosic R, Zakharov A, Johnston M. Does neonatal cerebrospinal fluid absorption occur via arachnoid projections or extracranial lymphatics? Am J Physiol Regul Integr Comp Physiol. 2002; 283(4):R869-76.

22. Zakharov A, Papaiconomou C, Koh L, Djenic J, Bozanovic-Sosic R, Johnston $M$. Integrating the roles of extracranial lymphatics and intracranial veins in cerebrospinal fluid absorption in sheep. Microvasc Res. 2004;67(1):96-104.

23. Ahn JH, Cho H, Kim JH, Kim SH, Ham JS, Park I, Suh SH, Hong SP, Song JH, Hong YK, et al. Meningeal lymphatic vessels at the skull base drain cerebrospinal fluid. Nature. 2019;572(7767):62-6.

24. Da Mesquita S, Louveau A, Vaccari A, Smirnov I, Cornelison RC, Kingsmore KM, Contarino C, Onengut-Gumuscu S, Farber E, Raper D, et al. Functional aspects of meningeal lymphatics in ageing and Alzheimer's disease. Nature. 2018;560(7717):185-91

25. Absinta M, Ha SK, Nair G, Sati P, Luciano NJ, Palisoc M, Louveau A, Zaghloul KA, Pittaluga S, Kipnis J, et al. Human and nonhuman primate meninges harbor lymphatic vessels that can be visualized noninvasively by MRI. eLife. 2017;6.

26. Ma Q, Ries M, Decker Y, Muller A, Riner C, Bucker A, Fassbender K, Detmar M, Proulx ST. Rapid lymphatic efflux limits cerebrospinal fluid flow to the brain. Acta Neuropathol. 2019;137(1):151-65.

27. Ma Q, Ineichen BV, Detmar M, Proulx ST. Outflow of cerebrospinal fluid is predominantly through lymphatic vessels and is reduced in aged mice. Nat Commun. 2017:8(1):1434.

28. Norwood JN, Zhang Q, Card D, Craine A, Ryan TM, Drew PJ. Anatomical basis and physiological role of cerebrospinal fluid transport through the murine cribriform plate. eLife. 2019;8.

29. Liu H, Ni Z, Chen Y, Wang D, Qi Y, Zhang Q, Wang S. Olfactory route for cerebrospinal fluid drainage into the cervical lymphatic system in a rabbit experimental model. Neural Regen Res. 2012;7(10):766-71.

30. Bradbury MW, Cserr HF, Westrop RJ. Drainage of cerebral interstitial fluid into deep cervical lymph of the rabbit. Am J Phys. 1981;240(4):F329-36.

31. Weller RO, Boche D, Nicoll JA. Microvasculature changes and cerebral amyloid angiopathy in Alzheimer's disease and their potential impact on therapy. Acta Neuropathol. 2009;118(1):87-102.

32. Bakker EN, Bacskai BJ, Arbel-Ornath M, Aldea R, Bedussi B, Morris AW, Weller $\mathrm{RO}$, Carare RO. Lymphatic clearance of the brain: perivascular, Paravascular and significance for neurodegenerative diseases. Cell Mol Neurobiol. 2016; 36(2):181-94. 
33. Zhang ET, Inman CB, Weller RO. Interrelationships of the pia mater and the perivascular (Virchow-Robin) spaces in the human cerebrum. J Anat. 1990; 170:111-23.

34. Iliff JJ, Wang M, Liao Y, Plogg BA, Peng W, Gundersen GA, Benveniste $H$, Vates GE, Deane R, Goldman SA, et al. A paravascular pathway facilitates CSF flow through the brain parenchyma and the clearance of interstitial solutes, including amyloid beta. Sci Transl Med. 2012;4(147):147ra111.

35. Schley D, Carare-Nnadi R, Please CP, Perry VH, Weller RO. Mechanisms to explain the reverse perivascular transport of solutes out of the brain. J Theor Biol. 2006;238(4):962-74.

36. Carare RO, Bernardes-Silva M, Newman TA, Page AM, Nicoll JA, Perry VH, Weller RO, et al. Neuropathol Appl Neurobiol. 2008;34(2):131-44.

37. Szentistvanyi I, Patlak CS, Ellis RA, Cserr HF. Drainage of interstitial fluid from different regions of rat brain. Am J Phys. 1984;246(6 Pt 2):F835-44.

38. Roberts KF, Elbert DL, Kasten TP, Patterson BW, Sigurdson WC, Connors RE, Ovod V, Munsell LY, Mawuenyega KG, Miller-Thomas MM, et al. Amyloidbeta efflux from the central nervous system into the plasma. Ann Neurol. 2014;76(6):837-44.

39. Wang J, Gu BJ, Masters CL, Wang YJ. A systemic view of Alzheimer disease insights from amyloid-beta metabolism beyond the brain. Nat Rev Neurol. 2017;13(10):612-23.

40. Mawuenyega KG, Sigurdson W, Ovod V, Munsell L, Kasten T, Morris JC, Yarasheski KE, Bateman RJ. Decreased clearance of CNS beta-amyloid in Alzheimer's disease. Science. 2010;330(6012):1774.

41. Yuede CM, Lee H, Restivo JL, Davis TA, Hettinger JC, Wallace CE, Young KL, Hayne MR, Bu G, Li CZ, et al. Rapid in vivo measurement of beta-amyloid reveals biphasic clearance kinetics in an Alzheimer's mouse model. J Exp Med. 2016;213(5):677-85.

42. Qosa H, Abuasal BS, Romero IA, Weksler B, Couraud PO, Keller JN, Kaddoumi A. Differences in amyloid-beta clearance across mouse and human bloodbrain barrier models: kinetic analysis and mechanistic modeling. Neuropharmacology. 2014;79:668-78.

43. Wang L, Zhang Y, Zhao Y, Marshall C, Wu T, Xiao M. Deep cervical lymph node ligation aggravates AD-like pathology of APP/PS1 mice. Brain Pathol. 2019;29(2):176-92.

44. Wen YR, Yang JH, Wang X, Yao ZB. Induced dural lymphangiogenesis facilities soluble amyloid-beta clearance from brain in a transgenic mouse model of Alzheimer's disease. Neural Regen Res. 2018;13(4):709-16.

45. Das MM, Godoy M, Chen S, Moser VA, Avalos P, Roxas KM, Dang I, Yanez A, Zhang W, Bresee $C$, et al. Young bone marrow transplantation preserves learning and memory in old mice. Commun Biol. 2019;2:73.

46. Malm TM, Koistinaho M, Parepalo M, Vatanen T, Ooka A, Karlsson S, Koistinaho J. Bone-marrow-derived cells contribute to the recruitment of microglial cells in response to beta-amyloid deposition in APP/PS1 double transgenic Alzheimer mice. Neurobiol Dis. 2005;18(1):134-42.

47. Zhao J, Li L, Leissring MA. Insulin-degrading enzyme is exported via an unconventional protein secretion pathway. Mol Neurodegener. 2009;4:4.

48. Miller BC, Eckman EA, Sambamurti K, Dobbs N, Chow KM, Eckman CB, Hersh $L B$, Thiele DL. Amyloid-beta peptide levels in brain are inversely correlated with insulysin activity levels in vivo. Proc Natl Acad Sci U S A. 2003;100(10): 6221-6.

49. Farris W, Mansourian S, Chang Y, Lindsley L, Eckman EA, Frosch MP, Eckman CB, Tanzi RE, Selkoe DJ, Guenette S. Insulin-degrading enzyme regulates the levels of insulin, amyloid beta-protein, and the beta-amyloid precursor protein intracellular domain in vivo. Proc Natl Acad Sci U S A. 2003;100(7): 4162-7.

50. Lim CS, Han JS. The antioxidant xanthorrhizol prevents amyloid-betainduced oxidative modification and inactivation of neprilysin. Biosci Rep. 2018;38(1). https://doi.org/10.1042/BSR20171611.

51. Yasojima K, Akiyama H, McGeer EG, McGeer PL. Reduced neprilysin in high plaque areas of Alzheimer brain: a possible relationship to deficient degradation of beta-amyloid peptide. Neurosci Lett. 2001;297(2):97-100.

52. Huang SM, Mouri A, Kokubo H, Nakajima R, Suemoto T, Higuchi M, Staufenbiel M, Noda Y, Yamaguchi H, Nabeshima T, et al. Neprilysin-sensitive synapse-associated amyloid-beta peptide oligomers impair neuronal plasticity and cognitive function. J Biol Chem. 2006;281(26):17941-51.

53. Hemming ML, Selkoe DJ. Amyloid beta-protein is degraded by cellular angiotensin-converting enzyme (ACE) and elevated by an ACE inhibitor. J Biol Chem. 2005;280(45):37644-50.

54. Zou K, Yamaguchi H, Akatsu H, Sakamoto T, Ko M, Mizoguchi K, Gong JS, Yu W, Yamamoto T, Kosaka K, et al. Angiotensin-converting enzyme converts amyloid beta-protein 1-42 (Abeta(1-42)) to Abeta(1-40), and its inhibition enhances brain Abeta deposition. J Neurosci. 2007;27(32):8628-35.

55. Lehmann DJ, Cortina-Borja M, Warden DR, Smith AD, Sleegers K, Prince JA, van Duijn CM, Kehoe PG. Large meta-analysis establishes the ACE insertiondeletion polymorphism as a marker of Alzheimer's disease. Am J Epidemiol. 2005;162(4):305-17.

56. Bertram L, McQueen MB, Mullin K, Blacker D, Tanzi RE. Systematic metaanalyses of Alzheimer disease genetic association studies: the AlzGene database. Nat Genet. 2007;39(1):17-23.

57. Bernstein KE, Koronyo Y, Salumbides BC, Sheyn J, Pelissier L, Lopes DH, Shah $\mathrm{KH}$, Bernstein EA, Fuchs DT, Yu JJ, et al. Angiotensin-converting enzyme overexpression in myelomonocytes prevents Alzheimer's-like cognitive decline. J Clin Invest. 2014;124(3):1000-12

58. Eckman EA, Reed DK, Eckman CB. Degradation of the Alzheimer's amyloid beta peptide by endothelin-converting enzyme. J Biol Chem. 2001;276(27): 24540-8.

59. Barker R, Love S, Kehoe PG. Plasminogen and plasmin in Alzheimer's disease. Brain Res. 2010;1355:7-15.

60. Humpel C. Organotypic vibrosections from whole brain adult Alzheimer mice (overexpressing amyloid-precursor-protein with the Swedish-Dutchlowa mutations) as a model to study clearance of beta-amyloid plaques. Front Aging Neurosci. 2015;7:47.

61. Yan P, Hu X, Song H, Yin K, Bateman RJ, Cirrito JR, Xiao Q, Hsu FF, Turk JW, $\mathrm{Xu} \mathrm{J}$, et al. Matrix metalloproteinase-9 degrades amyloid-beta fibrils in vitro and compact plaques in situ. J Biol Chem. 2006;281(34):24566-74.

62. Theriault P, ElAli A, Rivest $S$. The dynamics of monocytes and microglia in Alzheimer's disease. Alzheimers Res Ther. 2015;7(1):41.

63. Fiala M, Lin J, Ringman J, Kermani-Arab V, Tsao G, Patel A, Lossinsky AS, Graves MC, Gustavson A, Sayre J, et al. Ineffective phagocytosis of amyloidbeta by macrophages of Alzheimer's disease patients. J Alzheimers Dis. 2005;7(3):221-32 discussion 255-262.

64. Halle M, Tribout-Jover P, Lanteigne AM, Boulais J, St-Jean JR, Jodoin R, Girouard MP, Constantin F, Migneault A, Renaud F, et al. Methods to monitor monocytes-mediated amyloid-beta uptake and phagocytosis in the context of adjuvanted immunotherapies. J Immunol Methods. 2015;424:6479.

65. Guo H, Zhao Z, Zhang R, Chen P, Zhang X, Cheng F, Gou X. Monocytes in the peripheral clearance of amyloid-beta and Alzheimer's disease. J Alzheimers Dis. 2019;68(4):1391-1400.2019.

66. Hochstrasser T, Weiss E, Marksteiner J, Humpel C. Soluble cell adhesion molecules in monocytes of Alzheimer's disease and mild cognitive impairment. Exp Gerontol. 2010;45(1):70-4.

67. Fiala M, Liu PT, Espinosa-Jeffrey A, Rosenthal MJ, Bernard G, Ringman JM, Sayre J, Zhang L, Zaghi J, Dejbakhsh S, et al. Innate immunity and transcription of MGAT-III and toll-like receptors in Alzheimer's disease patients are improved by bisdemethoxycurcumin. Proc Natl Acad Sci U S A. 2007;104(31):12849-54.

68. Bradshaw EM, Chibnik LB, Keenan BT, Ottoboni L, Raj T, Tang A, Rosenkrantz LL, Imboywa S, Lee M, Von Korff A, et al. CD33 Alzheimer's disease locus: altered monocyte function and amyloid biology. Nat Neurosci. 2013;16(7): $848-50$

69. Zhao Y, Wu X, Li X, Jiang LL, Gui X, Liu Y, Sun Y, Zhu B, Pina-Crespo JC, Zhang $M$, et al. TREM2 is a receptor for beta-amyloid that mediates microglial function. Neuron. 2018;97(5):1023-1031 e1027.

70. Hawkes CA, McLaurin J. Selective targeting of perivascular macrophages for clearance of beta-amyloid in cerebral amyloid angiopathy. Proc Natl Acad Sci U S A. 2009;106(4):1261-6.

71. Michaud JP, Bellavance MA, Prefontaine P, Rivest S. Real-time in vivo imaging reveals the ability of monocytes to clear vascular amyloid beta. Cell Rep. 2013;5(3):646-53.

72. Simard AR, Soulet D, Gowing G, Julien JP, Rivest S. Bone marrow-derived microglia play a critical role in restricting senile plaque formation in Alzheimer's disease. Neuron. 2006;49(4):489-502.

73. Rogers J, Li R, Mastroeni D, Grover A, Leonard B, Ahern G, Cao P, Kolody H, Vedders $L$, Kolb WP, et al. Peripheral clearance of amyloid beta peptide by complement C3-dependent adherence to erythrocytes. Neurobiol Aging. 2006;27(12):1733-9.

74. Brubaker WD, Crane A, Johansson JU, Yen K, Garfinkel K, Mastroeni D, Asok P, Bradt B, Sabbagh M, Wallace TL, et al. Peripheral complement interactions with amyloid beta peptide: erythrocyte clearance mechanisms. Alzheimer's Dement : J Alzheimers Assoc. 2017;13(12):1397-409. 
75. Johansson JU, Brubaker WD, Javitz H, Bergen AW, Nishita D, Trigunaite A, Crane A, Ceballos J, Mastroeni D, Tenner AJ, et al. Peripheral complement interactions with amyloid beta peptide in Alzheimer's disease: polymorphisms, structure, and function of complement receptor 1. Alzheimers Dement : J Alzheimers Assoc. 2018;14(11):1438-49.

76. Jansen IE, Savage JE, Watanabe K, Bryois J, Williams DM, Steinberg S, Sealock J, Karlsson IK, Hagg S, Athanasiu L, et al. Genome-wide meta-analysis identifies new loci and functional pathways influencing Alzheimer's disease risk. Nat Genet. 2019;51(3):404-13.

77. Crane A, Brubaker WD, Johansson JU, Trigunaite A, Ceballos J, Bradt B, Glavis-Bloom C, Wallace TL, Tenner AJ, Rogers J. Peripheral complement interactions with amyloid beta peptide in Alzheimer's disease: 2. Relationship to amyloid beta immunotherapy. Alzheimers Dement : J Alzheimers Assoc. 2018;14(2):243-52.

78. Chen $\mathrm{SH}, \mathrm{Bu} X \mathrm{~L}$, Jin WS, Shen LL, Wang J, Zhuang ZQ, Zhang T, Zeng F, Yao $X Q$, Zhou HD, et al. Altered peripheral profile of blood cells in Alzheimer disease: a hospital-based case-control study. Medicine (Baltimore). 2017; 96(21):e6843.

79. Biere AL, Ostaszewski B, Stimson ER, Hyman BT, Maggio JE, Selkoe DJ. Amyloid beta-peptide is transported on lipoproteins and albumin in human plasma. J Biol Chem. 1996;271(51):32916-22.

80. Oliveira SM, Ribeiro CA, Cardoso I, Saraiva MJ. Gender-dependent transthyretin modulation of brain amyloid-beta levels: evidence from a mouse model of Alzheimer's disease. J Alzheimers Dis. 2011;27(2):429-39.

81. Schwarzman AL, Gregori L, Vitek MP, Lyubski S, Strittmatter WJ, Enghilde JJ, Bhasin R, Silverman J, Weisgraber KH, Coyle PK, et al. Transthyretin sequesters amyloid beta protein and prevents amyloid formation. Proc Natl Acad Sci U S A. 1994:91(18):8368-72.

82. Martel CL, Mackic JB, Matsubara E, Governale S, Miguel C, Miao W, McComb JG, Frangione B, Ghiso J, Zlokovic BV. Isoform-specific effects of apolipoproteins E2, E3, and E4 on cerebral capillary sequestration and blood-brain barrier transport of circulating Alzheimer's amyloid beta. Neurochem. 1997;69(5):1995-2004.

83. Zlokovic BV, Martel CL, Matsubara E, McComb JG, Zheng G, McCluskey RT, Frangione B, Ghiso J. Glycoprotein 330/megalin: probable role in receptormediated transport of apolipoprotein $\mathrm{J}$ alone and in a complex with Alzheimer disease amyloid beta at the blood-brain and blood-cerebrospinal fluid barriers. Proc Natl Acad Sci U S A. 1996:93(9):4229-34.

84. Sagare A, Deane R, Bell RD, Johnson B, Hamm K, Pendu R, Marky A, Lenting PJ, Wu Z, Zarcone T, et al. Clearance of amyloid-beta by circulating lipoprotein receptors. Nat Med. 2007;13(9):1029-31.

85. Sparks DL. Cholesterol metabolism and brain amyloidosis: evidence for a role of copper in the clearance of Abeta through the liver. Curr Alzheimer Res. 2007;4(2):165-9.

86. Koudinov A, Matsubara E, Frangione B, Ghiso J. The soluble form of Alzheimer's amyloid beta protein is complexed to high density lipoprotein 3 and very high density lipoprotein in normal human plasma. Biochem Biophys Res Commun. 1994;205(2):1164-71.

87. Robert J, Button EB, Yuen B, Gilmour M, Kang K, Bahrabadi A, Stukas S, Zhao W, Kulic I, Wellington CL. Clearance of beta-amyloid is facilitated by apolipoprotein E and circulating high-density lipoproteins in bioengineered human vessels. eLife. 2017;6.

88. Tamaki C, Ohtsuki S, Iwatsubo T, Hashimoto T, Yamada K, Yabuki C, Terasaki T. Major involvement of low-density lipoprotein receptor-related protein 1 in the clearance of plasma free amyloid beta-peptide by the liver. Pharm Res. 2006;23(7):1407-16.

89. Sehgal N, Gupta A, Valli RK, Joshi SD, Mills JT, Hamel E, Khanna P, Jain SC, Thakur SS, Ravindranath V. Withania somnifera reverses Alzheimer's disease pathology by enhancing low-density lipoprotein receptor-related protein in liver. Proc Natl Acad Sci U S A. 2012;109(9):3510-5.

90. Kress GJ, Liao F, Dimitry J, Cedeno MR, FitzGerald GA, Holtzman DM, Musiek ES. Regulation of amyloid-beta dynamics and pathology by the circadian clock. J Exp Med. 2018;215(4):1059-68.

91. Chauhan R, Chen KF, Kent BA, Crowther DC. Central and peripheral circadian clocks and their role in Alzheimer's disease. Dis Model Mech. 2017; 10(10):1187-99.

92. Ghiso J, Calero M, Matsubara E, Governale S, Chuba J, Beavis R, Wisniewski T, Frangione B. Alzheimer's soluble amyloid beta is a normal component of human urine. FEBS Lett. 1997:408(1):105-8.

93. Liu YH, Xiang Y, Wang YR, Jiao SS, Wang QH, Bu XL, Zhu C, Yao XQ, Giunta $B, T a n J$, et al. Association between serum amyloid-Beta and Renal functions: implications for roles of kidney in amyloid-Beta clearance. Mol Neurobiol. 2015;52(1):115-9.

94. Sakai K, Senda T, Hata R, Kuroda M, Hasegawa M, Kato M, Abe M, Kawaguchi K, Nakai S, Hiki Y, et al. Patients that have undergone hemodialysis exhibit lower amyloid deposition in the brain: evidence supporting a therapeutic strategy for Alzheimer's disease by removal of blood amyloid. J Alzheimers Dis. 2016;51(4):997-1002.

95. Etgen T, Chonchol M, Forstl H, Sander D. Chronic kidney disease and cognitive impairment: a systematic review and meta-analysis. Am J Nephrol. 2012:35(5):474-82.

96. Guo Z, Liu X, Cao Y, Hou H, Chen X, Chen Y, Huang F, Chen W. Common $1 \mathrm{H}-\mathrm{MRS}$ characteristics in patients with Alzheimer's disease and vascular dementia diagnosed with kidney essence deficiency syndrome: a preliminary study. Altern Ther Health Med. 2017;23(3):12-8.

97. Radic J, Ljutic D, Radic M, Kovacic V, Dodig-Curkovic K, Sain M. Kidney transplantation improves cognitive and psychomotor functions in adult hemodialysis patients. Am J Nephrol. 2011;34(5):399-406.

98. Miwa K, Tanaka M, Okazaki S, Furukado S, Yagita Y, Sakaguchi M, Mochizuki H, Kitagawa K. Chronic kidney disease is associated with dementia independent of cerebral small-vessel disease. Neurology. 2014 82(12):1051-7.

99. Joachim CL, Mori H, Selkoe DJ. Amyloid beta-protein deposition in tissues other than brain in Alzheimer's disease. Nature. 1989;341(6239):226-30.

100. Tani Y, Uchida K, Uetsuka K, Nakamura S, Nakayama H, Goto N, Doi K. Amyloid deposits in the gastrointestinal tract of aging dogs. Vet Pathol. 1997;34(5):415-20.

101. Zhuang ZQ, Shen LL, Li WW, Fu X, Zeng F, Gui L, Lu Y, Cai M, Zhu C, Tan YL, et al. Gut microbiota is altered in patients with Alzheimer's disease. J Alzheimers Dis. 2018;63(4):1337-46.

102. Li B, He Y, Ma J, Huang P, Du J, Cao L, Wang Y, Xiao Q, Tang H, Chen S. Mild cognitive impairment has similar alterations as Alzheimer's disease in gut microbiota. Alzheimers Dement : J Alzheimers Assoc. 2019;15(10):1357-66.

103. Akerman SC, Hossain S, Shobo A, Zhong Y, Jourdain R, Hancock MA, George K, Breton L, Multhaup G. Neurodegenerative disease-related proteins within the epidermal layer of the human skin. J Alzheimers Dis. 2019:69(2):463-78.

104. Kummer C, Wehner S, Quast T, Werner S, Herzog V. Expression and potential function of beta-amyloid precursor proteins during cutaneous wound repair. Exp Cell Res. 2002;280(2):222-32.

105. Hoffmann J, Twiesselmann C, Kummer MP, Romagnoli P, Herzog V. A possible role for the Alzheimer amyloid precursor protein in the regulation of epidermal basal cell proliferation. Eur J Cell Biol. 2000;79(12):905-14.

106. Zaghi J, Goldenson B, Inayathullah M, Lossinsky AS, Masoumi A, Avagyan H, Mahanian M, Bernas M, Weinand M, Rosenthal MJ, et al. Alzheimer disease macrophages shuttle amyloid-beta from neurons to vessels, contributing to amyloid angiopathy. Acta Neuropathol. 2009;117(2):111-24.

107. Frenkel D, Wilkinson K, Zhao L, Hickman SE, Means TK, Puckett L, Farfara D, Kingery ND, Weiner HL, El Khoury J. Scaral deficiency impairs clearance of soluble amyloid-beta by mononuclear phagocytes and accelerates Alzheimer's-like disease progression. Nat Commun. 2013;4:2030.

108. Zenaro E, Pietronigro E, Della Bianca V, Piacentino G, Marongiu L, Budui S, Turano E, Rossi B, Angiari S, Dusi S, et al. Neutrophils promote Alzheimer's disease-like pathology and cognitive decline via LFA-1 integrin. Nat Med. 2015;21(8):880-6.

109. Wallin K, Solomon A, Kareholt I, Tuomilehto J, Soininen H, Kivipelto M. Midlife rheumatoid arthritis increases the risk of cognitive impairment two decades later: a population-based study. J Alzheimers Dis. 2012; 31(3):669-76.

110. Gaur S, Agnihotri R. Alzheimer's disease and chronic periodontitis: is there an association? Geriatr Gerontol Int. 2015;15(4):391-404.

111. Gao HM, Hong JS. Why neurodegenerative diseases are progressive: uncontrolled inflammation drives disease progression. Trends Immunol. 2008;29(8):357-65.

112. Tamaki C, Ohtsuki S, Terasaki T. Insulin facilitates the hepatic clearance of plasma amyloid beta-peptide (1 40) by intracellular translocation of lowdensity lipoprotein receptor-related protein 1 (LRP-1) to the plasma membrane in hepatocytes. Mol Pharmacol. 2007;72(4):850-5.

113. Wang YR, Wang QH, Zhang T, Liu YH, Yao XQ, Zeng F, Li J, Zhou FY, Wang $L$, Yan JC, et al. Associations between hepatic functions and plasma amyloid-Beta levels-implications for the capacity of liver in peripheral amyloid-Beta clearance. Mol Neurobiol. 2017;54(3):2338-44. 
114. Nho K, Kueider-Paisley A, Ahmad S, MahmoudianDehkordi S, Arnold M, Risacher SL, Louie G, Blach C, Baillie R, Han X, et al. Association of Altered Liver Enzymes with Alzheimer Disease Diagnosis, cognition, neuroimaging measures, and cerebrospinal fluid biomarkers. JAMA Netw Open. 2019;2(7): e197978.

115. Matsuzaki T, Sasaki K, Hata J, Hirakawa Y, Fujimi K, Ninomiya T, Suzuki SO, Kanba S, Kiyohara Y, Iwaki T. Association of Alzheimer disease pathology with abnormal lipid metabolism: the Hisayama study. Neurology. 2011; 77(11):1068-75.

116. Kunkle BW, Grenier-Boley B, Sims R, Bis JC, Damotte V, Naj AC, Boland A, Vronskaya M, van der Lee SJ, Amlie-Wolf A, et al. Genetic meta-analysis of diagnosed Alzheimer's disease identifies new risk loci and implicates Abeta, tau, immunity and lipid processing. Nat Genet. 2019;51(3):414-30.

117. Yamazaki Y, Zhao N, Caulfield TR, Liu CC, Bu G. Apolipoprotein E and Alzheimer disease: pathobiology and targeting strategies. Nat Rev Neurol. 2019;15(9):501-18.

118. Madero M, Gul A, Sarnak MJ. Cognitive function in chronic kidney disease. Semin Dial. 2008;21(1):29-37.

119. Yakushiji $Y$, Nanri $Y$, Hirotsu $T$, Nishihara M, Hara M, Nakajima J, Eriguchi M, Nishiyama M, Hara H, Node K. Marked cerebral atrophy is correlated with kidney dysfunction in nondisabled adults. Hypertens Res. 2010;33(12):1232-7.

120. Janson J, Laedtke T, Parisi JE, O'Brien P, Petersen RC, Butler PC. Increased risk of type 2 diabetes in Alzheimer disease. Diabetes. 2004;53(2):474-81.

121. Sims-Robinson C, Kim B, Rosko A, Feldman EL. How does diabetes accelerate Alzheimer disease pathology? Nat Rev Neurol. 2010;6(10):551-9.

122. Jay TR, Miller CM, Cheng PJ, Graham LC, Bemiller S, Broihier ML, Xu G, Margevicius D, Karlo JC, Sousa GL, et al. TREM2 deficiency eliminates TREM2+ inflammatory macrophages and ameliorates pathology in Alzheimer's disease mouse models. J Exp Med. 2015;212(3):287-95.

123. Ordonez-Gutierrez L, Posado-Fernandez A, Ahmadvand D, Lettiero B, Wu L, Anton M, Flores O, Moghimi SM, Wandosell F. ImmunoPEGliposome-mediated reduction of blood and brain amyloid levels in a mouse model of Alzheimer's disease is restricted to aged animals. Biomaterials. 2017;112:141-52.

124. Carradori D, Balducci C, Re F, Brambilla D, Le Droumaguet B, Flores O, Gaudin A, Mura S, Forloni G, Ordonez-Gutierrez L, et al. Antibody-functionalized polymer nanoparticle leading to memory recovery in Alzheimer's disease-like transgenic mouse model. Nanomedicine. 2018;14(2):609-18.

125. Liu YH, Giunta B, Zhou HD, Tan J, Wang YJ. Immunotherapy for Alzheimer disease: the challenge of adverse effects. Nat Rev Neurol. 2012;8(8):465-9.

126. Costa-Marques L, Arnold K, Pardon MC, Leovsky C, Swarbrick S, Fabian C, Stolzing A. Transplantation of bone marrow derived macrophages reduces markers of neuropathology in an APP/PS1 mouse model. Transl Neurodegener. 2019;8:33

127. Liu Y, Studzinski C, Beckett T, Guan H, Hersh MA, Murphy MP, Klein R, Hersh LB. Expression of neprilysin in skeletal muscle reduces amyloid burden in a transgenic mouse model of Alzheimer disease. Mol Ther. 2009;17(8):1381-6.

128. Guan H, Liu Y, Daily A, Police S, Kim MH, Oddo S, LaFerla FM, Pauly JR, Murphy MP, Hersh LB. Peripherally expressed neprilysin reduces brain amyloid burden: a novel approach for treating Alzheimer's disease. J Neurosci Res. 2009;87(6):1462-73.

129. Koronyo-Hamaoui M, Sheyn J, Hayden EY, Li S, Fuchs DT, Regis GC, Lopes $\mathrm{DHJ}$, Black KL, Bernstein KE, Teplow DB, et al. Peripherally derived angiotensin converting enzyme-enhanced macrophages alleviate Alzheimer-related disease. Brain. 2019;143(1):336-58.

130. Liu Y, Guan H, Beckett TL, Juliano MA, Juliano L, Song ES, Chow KM, Murphy MP, Hersh LB. In vitro and in vivo degradation of Abeta peptide by peptidases coupled to erythrocytes. Peptides. 2007;28(12):2348-55.

131. Sun HL, Li WW, Zhu C, Jin WS, Liu YH, Zeng F, Wang YJ, Bu XL. The correlations of plasma and cerebrospinal fluid amyloid-Beta levels with platelet count in patients with Alzheimer's disease. Biomed Res Int. 2018; 2018:7302045

132. Jin WS, Shen LL, Bu XL, Zhang WW, Chen SH, Huang ZL, Xiong JX, Gao CY, Dong Z, He YN, et al. Peritoneal dialysis reduces amyloid-beta plasma levels in humans and attenuates Alzheimer-associated phenotypes in an APP/PS1 mouse model. Acta Neuropathol. 2017;134(2):207-20.

133. Ding XL, Lei P. Plasma replacement therapy for Alzheimer's disease. Neurosci Bull. 2020;36(1):89-90.

134. Liu YH, Wang YR, Xiang Y, Zhou HD, Giunta B, Manucat-Tan NB, Tan J, Zhou XF, Wang YJ. Clearance of amyloid-beta in Alzheimer's disease: shifting the action site from center to periphery. Mol Neurobiol. 2015:51(1):1-7.

Ready to submit your research? Choose BMC and benefit from:

- fast, convenient online submission

- thorough peer review by experienced researchers in your field

- rapid publication on acceptance

- support for research data, including large and complex data types

- gold Open Access which fosters wider collaboration and increased citations

- maximum visibility for your research: over $100 \mathrm{M}$ website views per year

At BMC, research is always in progress.

Learn more biomedcentral.com/submissions 